\title{
AKIBAT HUKUM SUATU BADAN USAHA PERSEROAN TERBATAS YANG DINYATAKAN PAILIT
}

\author{
Christopher Panal Lumban Gaol, S.H., M.Hum \\ Fakultas Hukum Universitas Katolik Santo Thomas, Medan, Indonesia \\ Email : C.thoperlg@gmail.com
}

\begin{abstract}
ABSTRAK
Prosedur pernyataan pailit dan pihak-pihak dalam kepailitan secara umum diajukan ke Pengadilan Niaga melalui panitera, Panitera menyampaikan permohonan pernyataan pailit kepada Ketua Pengadilan Negeri (Niaga) dalam waktu paling lambat 1 x 24 jam. Pemanggilan Sidang 7 (tujuh) hari sebelum sidang pertama di mulai. Sidang pemeriksaan atas permohonan pernyataan pertama di selenggarakan dalam jangka waktu paling lambat 20 hari terhitung sejak tanggal permohonan di daftarkan.

Akibat hukum yang timbul terhadap perseroan terbatas yang dinyatakan Pailit bahwa seluruh harta kekayaan dari PT tersebut jatuh dalam penyitaan oleh Balai Harta Peninggalan, dan yang melakukan pengurusan dan pemberesan harta pailit adalah kurator dan Hakim pengawas. Pemberesan dan pengurusan harta pailit dan yang menyebabkan berakhirnya kepailitan yakni harta debitur pailit di likuidasi yang di lakukan oleh kurator atas hasil likuidasi kurator mendistribusikannya kepada masingmasing kreditur tersebut yang piutangnya telah diakui dalam proses pencocokan hutang sebagaimana ditentukan oleh Undang-undang, maka berakhirlah kepailitan itu.
\end{abstract}

Kata Kunci : Akibat Hukum, Badan Usaha, Perseroan Terbatas, Pailit

ABSTRACT
Bankruptcy declaration procedures and parties to bankruptcy are generally submitted to the Commercial Court through the clerk of the court, the clerk of the court submits a bankruptcy declaration to the Head of the District Court (Commerce) within 1 x 24 hours at the latest. Summons to the Session 7 (seven) days before the first trial begins. The examination session on the application for the first statement shall be held within 20 days from the date the application was registered.

The legal consequence that arises for a limited company that is declared bankrupt is that all the assets of the PT have been confiscated by the Balai Harta Peninggalan, and those who carry out the management and settlement of bankruptcy assets are the curator and the supervisory judge. Settlement and management of bankruptcy assets and those that cause the end of bankruptcy, namely the assets of bankrupt debtors are liquidated by the curator on the result of liquidation, the curator distributes them to each of these creditors whose receivables have been recognized in the debt matching process as determined by law, then the bankruptcy ends that.

Keywords: Legal Consequences, Business Entities, Limited Liability Companies, Bankruptcy

\section{A. PENDAhULUAN}

Salah satu usaha yang dilakukan dalam memenuhi kebutuhan manusia adalah dengan mendirikan suatu badan usaha baik secara perseorangan maupun dengan bekerja sama dengan badan usaha lain sesuai dengan ketentuan yang berlaku. Badan usaha yang dibentuk dapat berupa badan usaha pengadaan barang ataupun jasa.

Pendirian suatu badan usaha dimaksudkan untuk mempermudah 
perwujudan tujuan yang akan dicapai, karena dengan adanya usaha yang dibentuk itu manusia akan saling berhubungan antara satu dengan lainnya sesuai dengan kebutuhan maupun kepentingan masing-masing. Pada prinsipnya perseroan terbatas dapat memiliki segala hak dan kewajiban yang dapat dimiliki oleh orang perorangan, dengan pengecualian halhal yang bersifat pribadi, yang hanya mungkin dilaksanakan oleh orang perorangan, seperti diatur dalam buku pertama dan sebagian dan buku kedua KUH Perdata tentang kewarisan. Melaksanakan hak dan kewajiban yang dimiliki tersebut, ilmu hukum telah merumuskan fungsi dan tugas dan masing-masing organ perorangan tersebut, yang berbeda satu sama lainnya. Organ/alat perlengkapan perseroan terbatas adalah terdiri dan 3 (tiga) bagian yaitu :

1. Rapat Umum Pemegang Saham (RUPS)

2. Pengurus/Direksi

3. Komisaris. ${ }^{1}$

Badan usaha tidak selalu dapat memberi harapan para pendirinya, tetapi ada kalanya menderita kerugian atau bangkrut (pailit), sehingga pada waktu tertentu tidak bisa memenuhi kewajiban hukumnya kepada pihak lain yang mempunyai hubungan hukum dengan badan usaha itu.

Mengetahui suatu badan usaha berada dalam keadaan bangkrut bukanlah persoalan mudah, tetapi harus melalui proses peradilan di Pengadilan Niaga dan Hakim Pengadilan Niaga yang mempunyai wewenang untuk memutuskan suatu badan usaha berada dalam keadaan pailit atau tidak. Bila Undang-undang No, 37 tahun 2004 tentang Kepailitan terdapat beberapa

1 Rochmad Sumitro, Hukum Perseroan Terbatas, Yayasan dan Wakaf, Lusto, Jakarta, 1993, hlm. 17. pihak yang terlibat dalam proses kepailitan di Pengadilan Niaga. Pihakpihak tersebut adalah antara lain:

1. Permohonan Pailit Menurut ketentuan Pasal 1 UU No. 4 tahun 1998, yang menjadi pemohon dalam kepailitan adalah salah satu dari pihak sebagi berikut:

a. Pihak debitur pailit

b. Salah satu atau lebih dari pihak kreditur

c. Pihak Kejaksaan jika menyangkut dengan kepailitan umum

d. Pihak Bank Indonesia jika debitunya adalah satu bank

e. Pihak badan Pengawas Pasar Modal jika debiturnya suatu perusahaan efek.

2. Hakim Majelis pada Pengadilan Niaga, yaitu Hakim Pengadilan Negeri yang telah menjadi Hakim Pengadilan Niaga berdasarkan keputusan Mahkamah Agung.

3. Hakim Pengawas yaitu Hakim yang bertugas melakukan pengawasan terhadap tindakan kurator dalam melakukan pemberesan harta pailit yang diangkat melalui keputusan perkara kepailitan

4. Kurator yaitu merupakan satusatunya pihak yang akan menangani seluruh kegiatan pemberesan termasuk pengurusan harta pailit. Kurator diangkat oleh Pengadilan bersamaan dengan putusan permohonan pernyataan pailit.

\section{B. PERUMUSAN MASALAH}

1. Bagaimana prosedur pernyataan pailit?

2. Bagaimana akibat hukum pailitnya badan usaha perseroan terbatas? 


\section{PEMBAHASAN}

\section{Pengertian Perseroan Terbatas}

Perseroan Terbatas (PT) adalah merupakan suatu persekutuan yang berbentuk badan hukum dan dipakai sebagai terjemahan dan Naamloze Vennostchap (NV). Istilah "terbatas "dalam PT tertuju pada tanggung jawab para persero atau pemegang saham yang luasnya hanya terbatas pada jumlah nominal nilai dan semua saham-saham yang dimiliki.

Pada mulanya Perseroan Terbatas (PT) ini diatur adalah KUH dagang, yaitu pada Pasal 36 sampai dengan Pasal 56 akan tetapi peraturan tentang perseroan terbatas yang diatur dalam KUH Dagang ini dirasakan tidak sesuai lagi dengan perkembangan ekonomi dan duanja usaha yang semakin pesat baik secara nasional maupun internasional sehingga pengaturan yang menyangkut perseroan terbatas (PT) tersebut diganti dan diatur dalam Undang-undang tersendiri yaitu UU No. 1 tahun 1995.

Menurut UUPT No. 1 tahun 1995 mendefinisikan perseroan terbatas sebagi suatu badan hukum yang didirikan berdasarkan perjanjian, melakukan usaha dengan modal dasar yang seimbang, terbagi dalam saham

Dari Batasan diberikan tersebut di atas ada lima hal pokok yang menjadi unsur dan perseroan tersebut adalah:
a. Perseroan Terbatas adalah merupakan suatu badan hukum
b. Didirikan berdasarkan perjanjian
c. Menjalankan uasaha tertentu
d. Memiliki modal yang terbagi dalam saham-saham
e. Memiliki persyaratan Undang- undang

\section{Pengertian dan Tujuan Kepailitan}

Sebelum menguraikan tentang kepailitan terlebih dahulu penulis menguraikan istilah kepailitan. Secara etimologi kepailitan berasal dan kata Pailit. Selanjutnya istilah pailit berasal dari bahasa Belanda "Failliet" yang mempunyai arti kata ganda yaitu sebagai kata benda dan kata sifat. Istilah failliet itu sendiri berasal dari bahasa Perancis yaitu faillite yang berarti kemogokan atau kemacetan pembayaran, sedangkan orang yang mogok atau berbenti membayar dalam bahasa Perancis disebut Le fail. Kata kerja failit artinya adalah gagal, sedangkan dalam bahasa Inggris di kenal dengan to fail dengan arti yang sama dan dalam bahasa latin disebut failure.

Kepailitan dalarn pengertian hukum mengandung unsur-unsur yang tersendiri yang dibatasi secara tajam, namun defenisi mengenai pengertian itu tidak ada dalam Undang-undang. Selanjutnya istilah failit itu dalam bahasa Belanda ialah faiyit dan failitsement sebagai kepailitan. Kemudian kepada negara-negara yang berbahasa inggris mempergunakan istilah bankrup dan bankrupty.

Kemudian menurut Viktor $\mathrm{M}$. Situmorang dan Hendri menyebutkan bahwa Kepailitan adalah sistem dari eksekusi atas seluruh kekayaan dan si debitur dinyatakan pailit mempunyai piutang dan untuk bersama-sama, yang pada waktu si debitur dinyatakan pailit mempunyai piutang dan untuk jumlah piutang yang masing-masing kreditur memiliki pada saat itu. ${ }^{2}$

Pengertian Kepailitan menurut Undang-undang No. 37 tahun 2000 tentang Kepailitan dan Penundaan Kewajiban Pembayaran sebagaimana yang terdapat dalam Pasal 1 butir I menyebutkan bahwa "Kepailitan adalah sita umum atas semua kekayaan debitur

2 Viktor M. Situmorang, Pengantar Hukum Kepailitan di Indonesia, Rineke Cipta, Jakarta, 2004, hlm. 17. 
pailit yang pengurusan dan pemberesannya dilakukan oleh kurator dibawah pengawasan Hakim, Pengawasan sebagaimana diatur dalam Undang-undang ini.

Selanjutnya menurut ketentuan Pasal 2 Undang-undang No. 37 tahun 2004 dikatakan bahwa syarat-syarat yang harus dipenuhi agar debitur dapat dinyatakan pailit adalah apabila debitur mempunyai dua atau lebib kreditur dan tidak membayar lunas sedikitnya atau hutang yang telah jatuh waktu dan dapat ditagih, dinyatakan pailit dengan putusan Pengadilan, baik atas permohonannya sendiri maupun atas permohonan satu atau lebih krediturnya. Jadi berdasarkan defenisi atau pengertian yang diberikan oleh para sarjana di atas, maka dapatkah ditarik unsur-unsur pailit itu adalah sebagai berikut:

a. Adanya sita dan eksekusi atas seluruh kekayaan debitur

b. Adanya hutang lebih dari Satu

c. Adanya lebih dan satu kreditur

d. Adanya hutang yang sudah jatuh tempo dan dapat ditagih

e. Sita itu semata-mata mengenai harta kekayaan

f. Sita dan eksekusi tersebut untuk kepentingan para krediturnya bersama-sama 20 .

Dari unsur-unsur tersebut diatas, dapatlah dipakai pedoman tentang pengertian kepailitan. Kepailitan merupakan realisasi dan Pasal 1131 dan Pasal 1132 KUH Perdata. Dalam KUH Perdata Pasal 1131 menyatakan bahwa "segala kebendaan si berhutang yang bergerak maupun yang tidak bergerak, baik yang sudah ada mapun yang akan ada dikemudian hari, menjadi tanggungan untuk segala penikatannya perorangan..

Selanjutnya dalam KUH Perdata Pasal 1132 dinyatakan pula bahwa "Kebendaan tersebut menjadi tanggungan bersama-sama bagi semua orang yang mengutangkan kepadanya, pendapatan, penjualan benda dibagibagi menurut keseimbangannya, yaitu menurut besar kecilnya piutang masingmasing kecuali apabila di antara yang berpiutang itu ada alasannya yang sah untuk didahulukan."3

Berdasarkan ketentuan kedua pasal tersebut di atas, dapat diambil kesimpulan bahwa:

a. Apabila si debitur tidak membayar hutangnya dengan sukarela atau tidak membayarnya walaupun telah ada putusan pengadilan yang menghukum supaya melunasi hutangnya atau karena tidak mampu membayar seluruh hutangnya, maka seluruh harta bendanya disita untuk dijual dan hasilnya penjualan itu dibagikan antara semua krediturnya, menurut besar kecilnya piutang masing-masing kreditur, kecuali apabila diantara kreditur ada alasannya yang sah untuk didahulukan.

Dengan perkataan lain hal tersebut diatas menentukan bahwa setiap kreditur berhak atas setiap bagian dan kekayaan si debiturnya untuk dipergunakan sebagai pembayaran atas piutangnya.

b. Semua kreditur mempunyai hak yang sama Bahwa semua kreditur mempunyal hak yang sama tanpa menghitamkan siapa yang lebih dahulu memberikan kredit kepada sikreditur yang bersangkutan.

c. Tidak ada nomor unit dari para kreditur yang didasarkan atas saat timbulnya piutang-piutang mereka.

Beberapa pengertian di atas, yang dimaksud dengan failit adalah suatu

3 R. Subekti, KUH Perdata, CEtakan Keduapuluh, Pradnya Paramita, Jakarta, 1986, hlm, 265, 
keadaan debitur yang telah berhenti atau tidak mampu membayar hutangnya yang sudah jatuh tempo kepada salah seorang atau beberapa kreditur setelah adanya putusan dari Pengadilan Niaga atau permintaan pihak-pihak yang berkepentingan, atas permintaan debitur sendiri, kreditur maupun atas permintaan lembaga kejaksaan dengan maksud agar seluruh harta kekayaan debitur disita dan selanjutnya dilelang/dijual dan basil penjualannya dibagi-bagikan kepada para kreditur dengan adil dan merata.

Maksud atau tujuan dari lembaga kepailitan adalah untuk mencegab sitaan dan eksekusi oleh seseorang kreditur atau lebih secara perorangan, atau untuk menghentikan sitaan atau eksekusi dengan sitaan atau eksekusi secara bersama-sama hasil penjualan kekayaan tersebut yang lazim disebut "budel" dapat dibagi-bagi secara adil antara seluruh kreditur dengan mengingat akan hak-hak para pemegang hak istimewa, gadai dan hipotek.

\section{Pihak-pihak Dalam Kepailitan}

Apabila diperhatikan Undangundang No. 37 tahun 2004 tentang Kepailitan terdapat beberapa pihak yang terlibat dalam proses kepailitan di Pengadilan Niaga. Adapun pihak-pihak tersebut adalah antara lain:

a. Permohoanan Pailit

Menurut ketentuan Pasal 1 UU No.

4 Tahun 1998, yang menjadi pemohon dalam kepailitan adalah salah satu dari pihak sebagi berikut:

1) Pihak debitur pailit

2) Salah satu atau lebih dan pihak kreditur

3) Pihak Kejaksaan jika menyangkut dengan kepailitan umum

4) Pihak Bank Indonesia jika debiturnya adalah satu bank
5) Pihak badan Pengawas Pasar Modal jika debiturnya adalah suatu perusahaan efek.

b. Hakim Majelis pada Pengadilan Niaga, yaitu Hakim Pengadilan Negeri yang telah diangkat menjadi Hakim Pengadilan Niaga berdasarkan keputusan Mahkamah Agung.

c. Hakim Pengawas yaitu Hakim yang bertugas melakukan pengawasan terhadap tindakan kurator dalam melakukan pemberesan harta pailit yang diangkat melalui keputusan perkara kepailitan

d. Kurator yaitu merupakan satusatunya pihak yang akan menangani seluruh kegiatan pemberesan termasuk pengurusan harta pailit. Kurator diangkat oleh Pengadilan bersamaan dengan putusan permohonan pernyataan pailit.

Menurut Undang-undang No. 37 tahun 2004 tentang kepailitan yang dapat diangkat menjadi kurator adalah:

a. Balai Harta Peninggalan (BHP), yaitu unit pelaksana penyelenggaraan hukum di bidang harta peninggalan dan perwalian dalam lingkungan Departemen Kehakhnan, yang berada di bawah dan bertanggung jawab langsung kepada Direktorat Perdata. Tugas BHP ialah mewakili dan mengurus kepentingan orangorang yang karena hukum atau keputusan hakim tidak dapat menjalani sendiri kepentingannya berdasarkan peraturan perundangundangan yang berlaku. Untuk menyelenggarakan tugasnya BHP mempunyai fungsi:
1) Melaksanakan penyelesaian masalah perwalian, pengampunan, ketidak hadiran dan harta peninggalan yang tak ada kuasanya dan lain-lain 
masalah yang diatur peruadang-undangan.

2) Melaksanakan penyelesaian pembukuan dan pendaftaran surat wasiat sesuai dengan peraturan undang-undang.

3) Melaksanakan penyelesaian masalah kepailitan sesuai dengan peraturan perundangundangan.

Di dalam penyelesaian kepailitan, BPH memiliki tugas sebagai berikut:

1) Mengumumkan keputusan hakim tentang pernyataan kepailitan di dalam Berita Negara dan surat-surat kabar yang disetujui oleh Hakim Pengawas.

2) Melakukan penyitaan terhadap harta-harta si pailit, berupa perhiasan, efek-efek, suratsurat berharga, uang tunai, dan benda-benda lainnya, kecuali barang-barang yang tersebut dalam Pasal $20 \mathrm{Fv}$.

3) Menyusun inventaris harta pailit dan daftar utang piutang si pailit.

4) Membuka semua surat-surat sipailit dan daftar utang piutang si pailit.

5) Memberikan uang na \pm kah kepada si pailit (yang diambilkan dan harta pailit), setelah mendapat izin dan hakim komisanis.

6) Menjual benda-benda si pailit, apabila dipandang bahwa benda-benda itu tidak tahan lama, dari hasil penjualannya dimasukkan menjadi kekayaan (boedel) pailit.

7) Membuat suatu akor (perdamaian) setelah terlebih dahulu mendapat persetujuan dari Hakim Komisaris, dan nasehat dan panitia para kneditor.
8) Berhak untuk meneruskan perusahaan si pailit atas izin dari Hakim Komisaris. Akan tetapi apabila ada panitia para kreditor, maka panitia mi tidak dapat memberikan usul atau persetujuan untuk meneruskan perusahaan si pailit tanpa perlu mendapat izin dari Hakim Komisaris.

b. Kurator lainnya, yang dimaksud dengan kurator lainnya adalah kurator yang bukan BLIP yang diusulkan oleh debitur dan kreditur dan yang memiliki indevensi, yang dapat menjadi kurator adalah:

1) Perorangan atau persekutuan perdata yang berdomisili di Indonesia yang memiliki keahlian khusus yang dibutuhkan dalam rangka mengurus dan atau membereskan harta pailit,

2) Telah terdaftar pada Departemen Kehakiman

c.Pengacara yang mempunyai ijin/kartu pengacara, yaitu sebagai wakil atau kuasa pihak kreditur maupun debitur didalam proses persidangan kepailitan.

Dalam perkara kepailitan terdapat beberapa pihak yang mempunyai peranan sesuai dengan masing-masing sebagaimana diharapkan oleh Undang-undang kepailitan.

\section{Prosedur Pernyataan Pailit}

Adapun yang menjadi prosedur dan pernyataan pailit secara umum dapat diuraikan sebagai berikut:

a. Bahwa permohonan pernyataan pailit diajukan ke Pengadilan Niaga melalui Panitera, selanjutnya Panitera melajutkan permohonan pernyataan diberikan tanda terima tertulis yang di tanda tangani panitera dengan tanggal 
yang sama dengan tanggal pendaftaran.

b. Panitera menyampai permohonan pernyataan pailit kepada Ketua Pengadilan Negeri (Niaga) dalam jangka waktu paling lambat 1 x 24 jam terhitung sejak tanggal permohonan di daftarkan.

c. Dalam jangka waktu paling lambat $2 \times 24$ jam terhitung sejak tanggal permohonan pernyataan dan menetapkan hari sidang.

d. Pemanggilan sidang ( 7 hari sebelum sidang pertama dimulai ).

e. Sidang pemeriksaan atas permohonan pernyataan pailit diselenggarakan dalam jangka waktu paling lambat 20 (dua puluh) hari terhitung sejak tanggal permohonan didaftarkan dan penyelenggaraan sidang dapat ditunda sampai dengan paling lama 25 (dua puluh lima) hari terhitung sejak tanggal permohonan didaftarkan, namun pemunduran itu hanya dapat dilakukan apabila ada permohonan dan debitur berdasarkan alasan yang cukup.

f. Putusan atas permohonan pemyataan pailit harus ditetapkan dalam jangka waktu paling lambat 30 (tiga puluh) hari terhitung sejak tanggal permohonan pernyataan pailit didaftarkan.

g. Dalam jangka waktu $2 \times 24$ jam terhitung sejak tanggal putusan atas permohonan pernyataan pailit ditetapkan, Pengadilan wajib menyampaikan putusan dengan surat dinas tercatat atau melalui kurir kepada debitur, kepada pihak yang mengajukan permohonan pernyataan pailit dan kepada kurator dan Hakim Pengawas, salman putusan pengadilan Niaga yang memuat secara lengkap pertimbangan hukum yang mendasari putusan tersebut (pasal 6 ayat 6 UUK).

Adapun kelengkapan permohonan yang harus diajukan ke Pengadilan Negeri/Niaga dalam suatu permohonan kepailitan adalah sebagai berikut:

a. Jika permohonan itu berasal dan perorangan, dokumen yang diserahkan antara lain :

1) Surat permohonan yang bermaterai ditujukan kepada Ketua Pengadilan Negeni/Niaga yang bersangkutan.

2) Ijin Pengacara yang telah dilegalisir/kartu Pengacara, permohonan itu diajukan seorang Pengacara sebagai kuasa permohon.

3) Surat kuasa khusus

4) Surat tanda bukti (KTP) dan suami istri masih berlaku

5) Persetujuan suami/istri yang dilegalisi

6) Daftar asset dan tanggung jawab

7) Neraca pembukuan terakhir (dalam hal si pemohon perseorangan itu memiliki perusahaan)

b. Jika permohonan itu adalah suatu badan maka dokumen yang dilampirkan adalah:

1) Surat permohonan bermaterai yang diajukan kepada Ketua Pengadilan Negeri/Niaga

2) Kartu Pengacara

3) Surat kuasa khusus

4) Akte pendaftaran perusahaan yang dilegalisir cap oleh kantor Perdagangan paling lambat 1 (satu) minggu sebelum permohonan didaftarkan.

5) Persetujuan tertulis dan semua mitra

6) Neraca keuangan terakhir

7) Nama serta semua alamat debitur dan kreditur/mitra usaha 
c. Jika permohonan itu adalah debitur berupa yayasan/assosiasi maka dokumen yang diperlukan adalah:

1) Surat permohonan bermaterai yang diajukan kepada Ketua Pengadilan Negeri Niaga yang bersangkutan.

2) Ijin pengacara yang dilegalisir/kartu Pengacara

3) Surat kuasa khusus

4) Akte pendaftaran yayasan lassosiasi yang dilegalisir (di cap) oleh kantor perdagangan paling lambat 1 (satu) minggu sebelum permohonan didaftarkan

5) Putusan para pengacara yang memutuskan untuk mengajukan permohonan pailit.

6) Anggaran Dasar/Anggaran Rumah Tangga

7) Neraca keuangan terakhir

8) Nama serta semua alamat debitur dan kreditur/mitra usalia

d. Apabila pemohon itu adalah kreditur, maka yang diperlukan adalah:

1) Surat permohonan bermaterai yang diajukan kepada Ketua Pengadilan Negeri/Niaga

2) Ijin Pengacara yang diegalisir/kartu Pengacara

3) Surat kuasa khusus

4) Surat perjanjian hutang

5) Perincian hutang yang tidak dibayar

6) Nama serta alamat masingmasing kreditur

7) Tanda kenal diri debitur

8) Ijin serta alamat mitra usaha

9) Jika menyangkut unsur asing maka surat permohonan diperlukan terjemahan dalam bahasa Indonesia dan bahasa Ingris melalui penterjemah resmi.

e. Apabila pemohon pailit adalah Perseroan Terbatas (PT) maka dokumen yang diperlukan adalah:
1) Surat pennohonan bermeterai yang diajukan kepada Ketua Pengadilan Negeri/Niaga.

2) Ijin Pengacara yang diegalisir/kartu Pengacara

3) Surat kuasa khusus

4) Akta Pendirian PT yang di legalisir (di cap) oleh kantor Perdagangan paling lambat 1 (satu) minggu sebelum permohonan didaftarkan.

5) Putusan sah Rapat Umum Pemegang Saham (RUPS) terakhir

6) Anggaran Dasar/Anggaran Rumah Tangga

7) Neraca keuangan terakhir

8) Nama, alamat semua kreditur

f. Apabila yang memohon pailit adalah kejaksaan, Bank Indonesia, Bapepan dokumen yang diperlukan adalah:

1) Surat permohonan bermeterai yang diajukan kepada Ketua Pengadilan Negeri/Niaga.

2) Surat Tugas/surat kuasa

3) ijin Pengacara yang diegalisir/kartu Pengacara

4) Surat kuasa khusus

5) Surat pendaftaran perusahaan Bank Perusahaan efek yang dilegalisfir (di cap) oleh kantor Perdagangan paling lambat 1 (satu) minggu sebelum permohonan didaftarkan.

6) Surat perjanjian hutang

7) Perincian hutang yang telah jatuh tempo/belum dibayar

8) Neraca keuangan berlebih

9) Daftar asset dan tanggungjawab

10) Nama, alamat semua debitur dan kreditur

Selanjutnya sesudah permohonan diterima oleh Pengadilan Negeri/Niaga yang berwenang, Hakim menetapkan hari, tanggal, jam dan tempat sidang. Pemeriksaan permohonan kepailitan dilakukan secara cepat dalam rapat 
permusyawaratan itu dengan majelis Hakim.

Pembicaraan permohonan kepailitan dilakukan dalam sidang tertutup, sedangkan putusannya diucapkan dalam sidang terbuka untuk umum. Putusan Pernyataan pailit baru dijatuhkan bila secara sumir terbukti bahwa keadaan berhenti membayar itu ada, Hakim dapat memerintahkan debitur untuk menghadap secara pribadi atau dengan kuasanya dengan surat tercatat. Hakim Pengadilan Negeri setelah mendengarkan keterangan para pihak dapat berusaha mendamaikan pihak yang bersengketa, apabila para pihak tidak mau berdamai, maka jalan terakhir bagi Hakim adalah menjatuhkan putusan pailit.

Adapun prosedur mengenai kepailitan ini, selanjutnya yang harus dilakukan adalah sebagai berikut:

a. Putusan pailit disampaikan kepada pam pihak baik debitur maupun pada kreditur.

b. Putusan pailit berkekuatan hukum tetap

c. Apabila kesepakatan (accord) oleh para pihak maka selanjutnya hakim memberikan homolongasi (mengesahkan perdamaian)

d. Atau dinyatakan insolvensi (debitur dalam keadaan baik mampu membayar hutangnya)

e. Dilakukan pengangkatan pihakpihak yang berwenang melakukan pengurusan harta pailit. Dilakukan peberesan (penyusunan daftar piutang dan pembagian kepailitan terakhir)

Apabila diperhatikan semua prosedur pernyataan pailit seperti di atas, dapat dilihat secara teoritis sangat sederhana, karena kalau dari segi waktunya, persoalan kepailitan itu harus tuntas selama 30 hari pada Pengadilan tingkat pertama, selama 60 hari pada tingkat kasasi dan 131 hari pada tingkat peninjauan kembali. Atau dengan kata lain bahwa pemerikasaan perkara kepailitan dan tingkat pertama sampai pada tingkat kasasi hanya dibutuhkan waktu selama 60 hari, dan sampai pada tingkat peninjauan kembali hanya 131 hari.

Adapun hukum acara yang diperlukan dalam proses kepailitan di Pengadilan Niaga adalah Hukum Acara Perdata biasa yaitu HIR dan RBG tetapi khusus untuk perkara kepailitan / penundaan pembayaran terdapat pengecualian-pengecualian terhadap hukum acara perdata yang berlaku umum yaitu:

a. Hanya Pengadilan khusus yang berwenang yaitu Pengadilan Niaga

b. Hakim khusus yang merupakan Hakim tetap ataupun Hakim ad hock.

c. Pembuktiannya bersifat sumir

d. Jangka waktu proses perkara singkat

e. Tidak mengenal lembaga banding akan tetapi langsung kasasi

f. Adanya Lembaga Hakim Pengawas

g. Adanya kurator

h. Permohonan pailit wajib oleh lawyer yang mempunyai ijin praktek

i. Putusan pailit bersifat serta-merta.

\section{Akibat Hukum Kepailitan}

Sebagai mana diketahui bahwa perseroan terbatas adalah merupakan yang berbentuk badan hukum (legal form) yang memiliki kapasitas-kapasitas yuridis yang sama dengan yang dimiliki oleh orang perorangan (natural person). Dengan demikian, maka perseroan terbatas dapat melakukan semua fungsi hukum dan orang perorangan, yaitu dapat dimiliki harta kekayaan, menggugat atau digugat, dapat membeli sesuatu atau menjual harta kekayaannya dapat menerima hibah sesuatu dari 
pihak lain, berhak menerima pengadian suatu tagihan yang menjadi hak orang lain, dapat menerima sesuatu hibah dan pihak lain, berhak menerima pengalihan atas sesuatu tagihan yang menjadi hak orang lain, dapat menerima dan memberikan pinjaman, dinyatakan pailit dan sebagainya.

Suatu perseroan terbatas berbeda dengan suatu persekutuan yang bukan merupakan suatu badan hukum dan tidak terpisah dari pihak para sekutu yang menjadi anggota para persekutuan itu, sebagai suatu badan hukum perseroan terbatas memiliki tanggungjawab yang berbeda dengan pemegang saham perseroan. Sebagai hukum yang terpisah yang terpisah dan pemegang sahamnya, perseroan terbatas dalam melakukan fungsi hukumnya bukan bertindak sebagai kuasa dan pemegang sahamnya, tetapi bertindak dan atas nama dirinya sendiri.

Pemegang saham bukan merupakan pihak dari perjanjian yang dibuat oleh persoan dengan pihak lain dan oleh karena itu pula pemegang saham tidak bethak memaksa pihak lain untuk melaksanakan kewajibannya itu. Sebagai konsekuensinya maka pihak ketiga tidak dapat menagih atau menggugat perseroan atas kewajiban hukum dari pemegang saham perseroan itu dan sebaliknya pula tidak berhak untuk menagih pihak ketiga atas kewajiban yang harus dibayarkan kepada pemegang saham perseroan.

Berdasarkan segala hal yang terurai diatas telah memberikan gambaran dengan jelas tentang perbedaan antara perseroan terbatas dengan perseroan lainnya. Khususnya mengenai tanggungjawab antara perseroan dengan perseroan terpisah, sedangkan perseroan yang bukan berbadan hukum, tanggung jawab adalah sebagai berikut: a. Seluruh harta kekayaan PT masuk dalam penyitaan. Harta pailit meliputi seluruh kekayaan debitur PT pada waktu putusan pailit diucapkan serta segala apa yang diperoleh PT selama kepailitan.

b. Kekuasaan direksi suatu perseroan terbatas dan badan hukum lainnya untuk mengelola perusahaan debitur atau badan hukum tersebut "terpasang" sekalipun mereka menjabat dalam jabatanya tersebut.

c. Pengurus perusahaan debitur itu menjadi functus officio.

d. Seluruh harta PT yang masuk dalam budel pailit diurus dan dikuasai kurator untuk kepentingan semua para kreditur dan hakim pengawas memimpin dan mengawasi pelaksanaan jalannya kepailitan.

e. Segala perikatan yang dilakukan direksi/pengurus PT selama kepailitan berlangsung adalah tanggung jawab dan pengurus sendiri dan tidak dapat dibayar dari harta pailit kecuali jika menguntungkan harta pailit.

Selanjutnya mengenai tanggung jawab para perseronya, bahwa hukum perseronya menentukan bahwa harta kekayaan pribadi para pemegang saham tidak dapat dijangkau oleh para kreditur untuk dijadikan sumber pelunasan hutang-hutang perseroan tersebut, sesuai dengan azas hukum perseroan terdapat tabir pemisah antara perseroan tersebut dengan pemegang saham. Sedangkan tanggung jawab pemegang saham terhadap hutang-hutang perseroan terbatas hanya pada modal saham yang disetorkan oleh pemegang saham kepada perseroan.

Sejalan dengan azas tersebut, menurut Pasal 3 ayat (1) UU No. 1 tahun 1995 tentang perseroan terbatas (UUPT). Pemegang saham perseroan 
tidak bertanggung jawab secara pribadi atau perikatan yang dibuat atas nama perseroan dan tidak bertanggung jawab atas kerugian perseroan melebihi nilai saham yang telah diambilnya.

Berkenaan dengan azas hukum tersebut, apabila suatu perseroan dinyatakan pailit dan hasil penjualan harta kekayaan (asset) perseroan tidak cukup untuk melunasi seluruh hutang perseroan, maka pemegang saham tidak bertanggung jawab untuk melunasi kekurangannya tersebut. Salah satu pihak dalam proses kepailitan adalah apa yang disebut dengan panitia kreditur yaitu pihak yang mewakili pihak kreditur untuk memperjuangkan segala kepentingan hukum dan para kreditur dalam kepailitan terutama untuk dapat dikembangkan seluruh atau sebagian hutangnya dan harta pailit sesuai dengan besar kecilnya piutang tersebut.

Sebagaimana diketahui, bahwa banyak akibat yunidis dan suatu kepailitan, termasuk akibat hukum terhadap kreditur, yaitu piutangnya yang ada pada debitur (dalam hal mi debitur perseroan terbatas (PT) tidak dapat dikembalikan secara penuh menurut perjanjian, karena harta kekayaan atau asset perseroan terbatas (PT) yang dinyatakan pailit setelah dilakukan pelelangan tidak cukup untuk menutupi seluruh hutang-hutangnya kepada para debitur.

Memperjuangkan haknya, maka didalam kepailitan kreditur dapat menempuh berbagai langkah di dalam kepailitan, sehingga diharapkan akan membawah akibat hukum yang lebih menguntungkan bagi kreditur, tindakantindakan hukum tersebut adalah antara lain sebagai berikut:

a. Krebitur dapat melakukan kompensasi piutang denga debitur (Perseroan Terbatas) asalkan dilakukan dengan itikad baik dan tidak dilarang dalam kontrak (Pasal 52, 53 dan 54 UUK) akibat dan dibenarkan kompensasi ini, maka kreditur yang bersangkutan mengkompensasikan piutangnya dengan hutangnya berarti dia menjadi lebih tinggi kedudukannya.

b. Kreditur dapat meminta untuk dibatalkannya transaksi yang dilakukan oleh debitur dengan pihak ketiga yang merugikan pihak kreditur dengan syaratsyarat yang diatur dalam Undangundang. Tindakkan seperti mi dalam kepailitan disebut action pauliana (Pasal $1341 \mathrm{BW}$ ).

c. Dengan adanya keputusan pailit terhadap suatu badan usaha perseroan terbatas (PT) maka perikatan yang dibuat PT tersebut dengan kreditur dimana perikatan dibuat setelah PT dinayatakan pailit, perikatan demikian tidak dapat dibayar dari harta pailit, kecuali jika perikatan itu mendatangkan keuntungan bagi harta pailit (pasal 23 UUK).

d. Dengan adanya putusan kepailitan, maka gugatan hukum berkenaan dengan hak dan kewajiban yang berhubungan dengan harta debitur pailit harus diajukan oleh atau terhadap kurator, karena debitur pailit tidak berhak mengurus dan mengusai harta pailit, jadi apabila kreditur mempunyai kepentingan. Dalam hal ini maka dia harus menggugat (PT) melalui kurator (BIIP) PT tersebut.

Dari uarain diatas, jelas diketahui bahwa akibat hukum kepailitan terhadap seorang kreditur suatu perseroan terbatas (PT) tidak dapat lagi dikembalikan secara normal sesuai dengan perjanjian, baik waktu maupun jumlahnya, karena harta pailit mungkin 
tidak sanggup lagi memenuhi pembayaran hutangnya secara sempurna dan harta pailit tersebut penguasaan dan pengurusannya telah beralih pada pihak lain yaitu kurator atau BHP, tetapi memaksimalkan akibat hukum tersebut kreditur dapat melakukan tindakantindakan hukum seperti yang telah diuraikan di atas.

\section{Pemberesan Harta Perseroan Terbatas yang Pailit}

Menurut ketentuan pasal 168 ayat (1) FV bila dalam pencocokan hutang (verifikasi) tidak ditawarkan perdamaian atau bila perdamaian yang ditawarkan ditolak atau bila pengesahan perdamaian tersebut oleh Pengadilan dengan pasti telah di tolak, maka demi hukum harta pailit itu berada dalam keadaan berhenti membayar.

Tindakan selanjutnya terhadap harta debitur pailit itu adalah melakukan likuidasi yang dilakukan oleh kurator. Atas hasil likuidasi itu kurator mendistribusikannya kepada masingmasing kreditur dalam rangka melunasi hutang debitur kepada masing-masing kreditur tersebut yang piutangnya telah diakui dalam proses pencocokan hutang atau verilikasi hutang-piutang oleh Undang-undang.

Menurut Pasal 170 ayat (1) UUK dengan tetap memperhatikan ketentuan pasal 12 ayat (1) UUK. Kurator harus memulai pemberesan dan menjual semua harta pailit tanpa perlu memperoleh persetujuan atau bantuan apabila:

a. Usul untuk mengurus perusahaan debitur pailit tidak diajukan dalam jangka waktu sebagai mana diatur dalam Undang-undang Kepailitan, usul tersebut telah diajukan tetapi telah ditolak.

b. Pengurusan terhadap debitur perseroan terbatas tersebut telah dihentikan Disamping ketentuan diatas bahwa dalam melakukan tugasnya kurator:

1) Tidak diharuskan memperoleh persetujuan dari atau menyampaikan pemberitahuan terlebih dahulu kepada debitur atau salah seorang debitur, meskipun dalam keadaan diluar kepailitan persetujuan atau persyaratan demikian dipersyaratkan.

2) Dapat dilakukan pinjaman dari pihak ke tiga, semata-mata dalam rangka menciptakan nilai harta positif.

Sesuai dengan ketentuan pasal 171 ayat (1) FV, semua barang PT tersebut harus dijual dimuka umum (dilelang) atau dilaksanakan dibawah seijin hakim pengawas. Barang-barang yang terhadapnya dapat dilakukan hak penahanan oleh para kreditur (hak retensi), wajib dikembalikan oleh kurator kedalam harta pailit dengan membayar tagihan-tagihan yang bersangkutan sepanjang hal yang demikian menguntungkan harta pailit.

Demi kepentigan pemberesan harta pailit, kurator dapat menggunakan debitur pailit yang dalam perseroan terbatas diwakili oleh direksi dengan memberikan upah yang besarnya ditentukan oleh Hakim Pengawas.

Sesuai dengan ketentuan Pasal 173 ayat (1) FV, setelah harta pailit berada dalam keadaan tidak mampu membayar berlaku ketentuan sebagai berikut:

a. Hakim pengawas pada hari, jam, tempat yang ditentukan dalam menandakan pembicaraan dengan kuratoe tentang tata cara pemberesan harta pailit itu.

b. Jika dianggap perlu, menyangkut tagihan yang belum dicocokan menurut ketentuan pasal $123 \mathrm{FV}$, Hakim pengawas mengadakan pencocokan hutang terhadap 
tagihan-tagihan yang diajukan setelah berakhirnya tenggang waktu sebagaimana ditetapkan dalam pasal 104 ayat (1) UUK.

c. Tagihan-tagihan ini, kurator harus melakukan hal-hal sebagaimana dimaksud dalam pasal 107 sampai dengan pasal $110 \mathrm{FV}$.

d. Kurator harus memanggil para kreditur tersebut secara tertulis dengan menyebutkan hal-hal yang akan dibicarakan dalam rapat.

e. Kurator harus mengiklankan panggilan yang sama dalam suratsurat kabar dengan cara sebagai mana dimaksud dalam pasal 13 UUK.

Menurut Pasal 175 ayat (1) FV menyebutkan bahwa:

a. Kurator harus membuat daftar mengenai pembayaran kepada para kreditur yang harus disahkan olek Hakim pengawas.

b. Daftar tersebut harus memuat pertelaahan tentang penerimaan dan pengeluaran (didalamnya termasuk upah kurator), nama kreditur, jumlah pencocokan tiap tagihan, begitu pula pembagian yang harus diterima oleh setiap tagihan tersebut.

c. Kepada para kreditur konkuren harus diberi suatu presentase yang ditentukan oleh Hakim pengawas.

d. Kepada para kreditur yang mempunyai hak istimewa, termasuk mereka yang hak istimewanya dibantah dan kepada para kreditur pemegang hak jaminan, sepanjang mereka belum menerima pembayaran menurut ketentuan dalam Pasal 56 UUK, diberi jumlah sesuai dengan hasil penjualan barang-barang tersebut mereka mempunyai hak istimewa atau mempunyai perikatan.

e. Bila jumlah tersebut kurang dari seluruh jumlah tagihan mereka, maka untuk kekuranganya mereka harus diberi presentase seperti halnya kepada para kreditur konkuren.

Sebagaimana ditentukan dalam Pasal 117 FV, semua biaya kepailitan pada umumnya dibebankan pada tiaptiap bagian dari harta pailit, kecuali berdasarkan ketentuan dalam pasal 56 UUK telah dilakukan penjualan sendiri oleh para kreditur pemegang hak jaminan.

Selanjutnya bahwa daftar pembagian yang telah disetujui oleh Hakim pengawas ditempatkan di kantor Pengadilan Niaga, sedangkan salinan daftar tersebut harus ditempatkan di kantor kurator, agar dapat dilihat oleh para kreditur selama tenggang waktu yang telah ditetapkan oleh Hakim pengawas mulai sejak daftar tersebut di tanda tangani pengesahannya. Kurator juga wajib mengumumkan dalam suratsurat kabar.

Berdasarkan ketentuan dalam Pasal 179 ayat (1) FV, bagi kreditur yang tidak setuju dengan daftar pembayaran yang sudah disahkan oleh Hakim pengawas tersebut dapat mengajukan perlawanan kepada panitera Pengadilan Niaga dengan cara mengirimkan surat keberatan disertai alasannya.

Apabila daftar pembagian telah berkedudukan hukum tetap daftar (pembagian) tersebut telah mengikat demi hukum, dan tindakan pemberesan telah dapat dilakukan oleh kurator. Selanjutnya menurut Pasal 188 ayat (1) FV, segera para kreditur yang telah dicocokkan tagihannya dibayar penuh tagihan mereka itu atau segera setelah daftar pembagian penutup memperoleh kekuatan hukum yang pasti, maka berakhirnya kepailitan itu. Selanjutnya kurator mengumumkan hak itu dalam surat-surat kabar. 


\section{KESIMPULAN}

1. Prosedur pernyataan pailit dan pihak-pihak dalam kepailitan secara umum diajukan ke Pengadilan Niaga melalui panitera, Panitera menyampaikan permohonan pernyataan pailit kepada Ketua Pengadilan Negeri (Niaga) dalam waktu paling lambat $1 \mathrm{x}$ 24 jam. Pemanggilan Sidang 7 hari sebelum sidang pertama di mulai. Sidang pemeriksaan atas permohonan pernyataan pertama di selenggarakan dalam jangka waktu paling lambat 20 hari terhitung sejak tanggal permohonan di daftarkan.

2. Akibat hukum yang timbul terhadap perseroan terbatas yang dinyatakan Pailit bahwa seluruh harta kekayaan dari PT tersebut jatuh dalam penyitaan oleh Balai Harta Peninggalan, dan yang melakukan pengurusan dan pemberesan harta pailit adalah kurator dan Hakim pengawas.

3. Pemberesan dan pengurusan harta pailit dan yang menyebabkan berakhirnya kepailitan yakni harta debitur pailit di likuidasi yang di lakukan oleh kurator atas hasil likuidasi kurator mendistribusikannya kepada masing-masing kreditur tersebut yang piutangnya telah diakui dalam proses pencocokan hutang sebagaimana ditentukan oleh Undang-undang, maka berakhirlah kepailitan itu.

\section{DAFTAR PUSTAKA}

Eljana S, 2000, Pengadilan Niaga Pelaksanaan dan Dampaknya, Mandar Maju, Bandung.
Gunawan Wijaya dan Ahmad Yani, 2009, Seri Hukum Bisnis Kepailitan, Raja Grafindo Persada, Jakarta.

2003, Seri Hukum Bisnis Perseroan Terbatas, Raja Grafindo Persada, Jakarta.

Hadi Setia Tunggal, 2005, UndangUndang Kepailitan dan Penundaan Kewajiban Pembayaran Utang, Harvarindo, Jakarta.

Munir Fuady, 1998, Hukum Pailit Dalam Teori dan Praktik, Citra Aditya Bakti, Bandung.

Rochmad Sumitro, 1993, Hukum Perseroan Terbatas, Yayasan dan Wakaf, Lusto, Jakarta.

R. Soeroso, 1991, Naskah Akademik Peraturan Perundang-undangan Tentang Kepailitan, Badan Pembinaan Hukum Nasional, Jakarta.

R.T. Sutanya R. Hadikusuma, 1995, Pengertian Pokok-pokok Hukum Perusahaan, Grafindo Persada, Jakarta.

Sutan Remy Syahdeni, 2002, Hukum Kepailitan Faillissements Verordening jo Undang-Undang Nomor 4 Tahun 1998, Mandar Maju, Bandung.

Victor M. Situmorang dan Hendri Soekarso. 2004, Pengantar Hukum Kepailitan di Indonesia, Rineke Cipta, Jakarta. 